\title{
SUBSTITUSI TEPUNG PISANG TERMODIFIKASI PADA PEMBUATAN KABOSOL TERHADAP KADAR GULA DARAH ORANG DEWASA
}

\section{ARTICLE INFO \\ Article history \\ Submitted : 2019-09-22 \\ Revised : 2019-10-18 \\ Accepted : 2019-12-21 \\ Keywords: \\ Kabosol \\ Modified banana flour \\ Resistant starch \\ Blood glucose levels}

\section{Kata Kunci:}

Kabosol

Tepung pisang modifikasi

Pati resisten

Kadar gula darah

\author{
Firdaus Syafii $^{1 凶}$, Yudianti ${ }^{1}$ \\ ${ }^{1}$ Jurusan Gizi Poltekkes Kemenkes Mamuju
}

\begin{abstract}
Appropriate treatment for people with diabetes mellitus (DM) is done by eating patterns to control blood glucose levels. The concept of the glycemic index (IG) is an approach to choose foods that are good in managing blood glucose levels. One of the local food ingredients that has the potential to be used as a substitute for flour and has a low GI is a banana. Modification of banana flour makes bananas have a lower glycemic index value that can control blood sugar levels. The purpose of this study was to determine the effect of modified banana flour substitution on the manufacture of kabosol on the value of an increase in adult blood sugar levels. Data collection in this study is random sampling. The design of this study was carried out using a Completely Randomized Design (CRD) using four variables, which is the composition of four modifications $(50 \%, 75 \%, 100 \%$,$) and 0 \%$ as a control. Data were processed using ANOVA test at a significance level of 5\%. Based on the results of the study, there was a significant effect of modified banana flour on making kabosol on the value of an increase in blood sugar $(p=0.007)$. The lowest increase in blood sugar levels was obtained from respondents who consumed banana flour substitute kabosol with a concentration of $100 \%$, which amounted to $3.1 \mathrm{mg} / \mathrm{dL}$. Kabosol with $100 \%$ modified banana flour substitutes can be used as functional food because it can control blood glucose levels. Suggestion in this study is necessary to optimize the process of modification of banana flour to further increase the levels of resistant starch and reduce the digestibility of starch.

Penanganan yang tepat bagi penderita diabetes melitus (DM) dilakukan dengan pengaturan pola makan untuk mengontrol kadar glukosa darah. Konsep indeks glikemik (IG) adalah pendekatan untuk memilih makanan yang baik dalam pengelolaan kadar glukosa darah. Salah satu bahan makanan lokal yang memiliki potensi untuk digunakan sebagai pengganti tepung dan memiliki IG rendah adalah pisang. Modifikasi tepung pisang membuat pisang memiliki nilai indeks glikemik yang lebih rendah yang dapat mengontrol kadar gula darah. Tujuan dari penelitian ini adalah untuk mengetahui pengaruh substitusi tepung pisang modifikasi pada pembuatan kabosol terhadap nilai kenaikan kadar gula darah orang dewasa. Desain penelitian ini dilakukan dengan menggunakan rancangan acak lengkap (RAL) menggunakan empat variabel konsentrasi tepung pisang termodifikasi $(50 \%, 75 \%, 100 \%$,) dan 0\% sebagai kontrol. Berdasarkan hasil penelitian, ada pengaruh yang signifikan dari tepung pisang modifikasi pada pembuatan kabosol terhadap nilai kenaikan gula darah $(\mathrm{p}=0,007)$. Kenaikan kadar gula darah terendah diperoleh dari responden yang mengkonsumsi kabosol substititusi tepung pisang dengan konsentrasu $100 \%$, yaitu sebesar $3.1 \mathrm{mg} / \mathrm{dL}$. Kabosol dengan susbstitusi tepung pisang modifikasi $100 \%$ dapat dijadikan sebagai pangan fungsional karena dapat mengontrol kadar glukosa dalam darah. Perlu dilakukan optimasi proses modifikasi tepung pisang untuk lebih meningkatkan kadar pati resisten dan menurunkan daya cerna pati.
\end{abstract}

Corresponding Author:

Firdaus Syafii

Jurusan Gizi Poltekkes Kemenkes Mamuju

Telp. 087866770774

Email: fsyafii.chemist@gmail.com

\section{PENDAHULUAN}

Gaya hidup yang tidak sehat dan pola makan yang buruk merupakan penyebab munculnya penyakit degeneratif. Penyakit degeneratif merupakan penyakit kronis yang mempunyai durasi panjang dan umumnya berkembang secara lambat dan termasuk katagori penyakit tidak menular. Salah satu penyakit degenaratif adalah Diabetes mellitus. Diabetes Mellitus merupakan penyakit gangguan metabolik akibat pankreas tidak dapat memproduksi cukup insulin atau 
terjadinya resistensi insulin sehingga menyebabkan gula darah meningkat. Berdasarkan estimasi terakhir IDF, sebanyak 382 juta orang didunia hidup dengan diabetes ditahun 2013. Diperkirakan akan meningkat menjadi 92 juta orang pada tahun 2035 . Diperkirakan dari 382 juta orang, sebanyak 175 juta diantaramya belum terdiagnosis, sehingga terancam berkembang progresif menjadi komplikasi tanpa disadari dan pencegahan (Infodatin Kemenkes, 2014).

Penanganan yang tepat bagi penderita diabetes melitus (DM) dilakukan dengan pengaturan pola makan untuk mengontrol kadar glukosa darah. Konsep Indeks Glikemik (IG) merupakan pendekatan untuk memilih pangan yang baik, khususnya pangan sumber karbohidrat. Pangan yang memiliki IG tinggi akan meningkatkan kadar glukosa darah dengan cepat dan begitu pula sebaliknya. konsep IG menjelaskan bahwa betapa pentingnya setiap orang untuk mengenal pangan yang bersumber dari karbohidrat berdasarkan kecepatannya meningkatkan kadar glukosa darah (Kustanti dkk., 2017).

Salah satu bahan pangan lokal yang berpotensi untuk pencegahan terjadinya penyakit Diabetes Mellitus dan memiliki IG rendah adalah pisang. Pisang memiliki nilai IG 46-51 yang lebih rendah dibandingkan dengan ubi jalar ungu (54 - 68) (Rimbawan dan Siagian 2004). Pisang merupakan salah satu komoditas buah tropis yang potensial di Indonesia, khususnya di Kabupaten Mamuju yang memiliki peluang sebagai salah satu bahan diversifikasi pangan. Potensi pada pisang didasarkan pada kandungan gizi yang tinggi seperti karbohidrat, mineral, vitamin dan kandungan serat yang memenuhi persyaratan sebagai komoditi pangan (Lumba dkk., 2017)

Salah satu diversifikasi pangan pada pisang untuk pencegahan terjadinya penyakit diabetes adalah dengan pembuatan tepung pisang termodifikasi. Hasil produk modifikasi tepung pisang akan menghasilkan pati resisten. Pati resisten merupakan fraksi dari pati yang tidak dapat dicerna oleh enzim pencernaan $(\alpha-$ amilase) dalam usus halus manusia tetapi masih dapat difermentasi oleh mikroflora usus. Pati resisten dapat berperan dalam mengurangi risiko timbulnya kanker kolon, mempunyai efek hipoglikemik, berperan sebagai prebiotik, dan memiliki nilai kalori yang rendah sehingga dapat dijadikan sebagai ingredien pangan yang rendah kalori (Kusnandar dkk. 2015)

Pisang Kepok banyak terdapat di kabupaten Mamuju. Penelitian terkait pati resisten pada tepung pisang kepok di Kabupaten Mamuju belum banyak dilakukan. Peningkatan kandungan pati resisten dapat meningkatkan sifat prebiotik dan menurunkan indeks glikemik pada pati tepung pisang kepok. Metode produksi pati resisten salah satunya dengan perlakuan hidrotermal dan retrogradasi. Pemanasan bertekanan pada suhu $121^{\circ} \mathrm{C}$ yang dilanjutkan dengan pendinginan (autoclaving-cooling) dapat digunakan untuk memproduksi pati resisten (Ozturk et al., 2011). Pada proses autoclaving-cooling, pembentukan pati resisten terjadi dengan cara retrogradasi pati yang terjadi saat pati disimpan pada suhu dingin. Oleh karena itu, proses pemanasan suhu tinggi (autoclaving) dan pendinginan (cooling) dilakukan untuk memfasilitasi proses retrogradasi tersebut. Proses autoclaving-cooling secara berulang menyebabkan pati teretrogradasi lebih banyak terbentuk yang ditunjukkan dari meningkatnya kadar pati resistennya (Nasrin dan Anal, 2014). Modifikasi produk makanan berbahan baku dengan IG rendah mampu memberikan kontribusi kecukupan gizi bagi penderita Diabetes mellitus (DM). Salah satu makanan yang disukai oleh hampir semua tingkat umur khususnya di Provinsi Sulawesi Barat adalah kue kabosol. Kabosol merupakan jenis makanan olahan berbasis pisang yang digemari oleh masyarakat suku Mandar di Sulawesi Barat. Makanan ini diproses secara sederhana, miliki cita rasa yang enak dan khas.

Pembuatan kue kabosol menggunakan bahan baku tepung pisang modifikasi telah dilakukan pada penelitian ini. Kue yang dibuat merupakan salah satu produk pangan fungsional karena memiliki sifat fungsional bagi kesehatan, yaitu dapat mengontrol kadar glukosa darah dan memiliki indeks glikemik yang rendah. Selain itu, Sifat fungsional tersebut dapat diperoleh melalui perubahan bahan baku utama yaitu penggantian terigu dengan bahan pangan lain yang memiliki kadar serat lebih tinggi dan IG yang relatif rendah. Produk hasil penelitian ini dapat menjadi salah satu pangan alternatif yang disukai dan pangan fungsional bagi penderita diabetes sekaligus dalam rangka diversifikasi pangan. 
Tujuan penelitian untuk menentukan pengaruh substitusi tepung pisang modifikasi pada pembuatan kabosol terhadap penurunan kenaikan kadar gula darah.

\section{BAHAN DAN METODE}

Penelitian ini merupakan penelitian eksperimental dengan desain pre-post test. Bahan utama untuk pembuatan tepung pisang termodifikasi adalah pisang kepok mentah. Bentuk pengambilan sampel pisang ada penelitian ini adalah random sampling.

Bahan untuk pembuatan kabosol terdiri atas tepung terigu, tepung pisang kepok termodifikasi, telur, pisang raja yang sudah matang, baking powder, vanili, minyak kelapa, air, serta bahan kimia untuk analisis daya cerna pati dan kadar pati resisten.

Penelitian ini terdiri atas 2 tahap utama, yaitu: pembuatan tepung pisang termodifikasi dan pembuatan kabosol dengan substitusi tepung pisang termodifikasi. Dalam pembuatan tepung pisang termodifikasi, buah pisang dikupas, dicuci dengan air bersih, diiris dengan ketebalan $\pm 2 \mathrm{~mm}$, direndam dalam akuades dengan perbandingan (1:2). Selanjutnya ditiriskan dan dipanaskan menggunakan otoklaf pada suhu $121^{\circ} \mathrm{C}$ selama 45 menit, selanjutnya didiamkan pada suhu ruang hingga dingin ( \pm 30 menit $)$ dan dinginkan pada suhu $4{ }^{\circ} \mathrm{C}$ selama 72 jam. Irisan pisang kemudian dikeringkan di oven pengering pada suhu $60^{\circ} \mathrm{C}$ selama 16 jam. Selanjutnya irisan pisang yang telah kering dihaluskan dengan disc mill dan diayak dengan saringan berukuran 80 mesh sehingga menghasilkan tepung pisang termodifikasi. Tepung yang dihasilkan dilakukan pengukuran Kadar Air (AOAC, 2005), daya cerna pati in vitro (Anderson dkk., 2002), dan Kadar Pati Resisten (AOAC, 1995)

Kabosol dibuat dengan cara mencampurkan bahan-bahan yaitu tepung terigu, baking powder, vanila, telur, dan pisang matang. Bahan-bahan yang digunakan dimasukan kedalam Loyang diaduk sampai homogen. Adonan yang sudah homogen ditambahkan minyak kelapa dan di homogenisasi sampai adonan tercampur sempurna. Selanjutnya adonan dikukus sampai berubah warna. Pada penelitian ini dilakukan substitusi tepung terigu dengan tepung pisang termodifikasi yang sudah dibuat pada penelitian tahap awal. Faktor yang digunakan pada penelitian ini adalah konsentrasi tepung pisang modifikasi. Konsentrasi tepung pisang modifikasi yang digunakan pada pembuatan kabosol adalah 25\%, 50\%, 75\% 100\%, dan 0\% sebagai kontrol.

Produk Kabosol tersubstitusi tepung pisang modifikasi setiap faktor selanjutnya dicobakan pada orang dewasa dan kemudian masing-masing diukur kenaikan kadar gula darah. Kenaikan kadar gula darah ditentukan dengan membandingkan gula darah puasa dan kadar gula darah sewaktu. Data yang dihasilkan Selanjutnya dilakukan analisis menggunakan uji ragam (ANOVA) menggunakan Rancangan Acak Lengkap (RAL) untuk mengetahui adanya pengaruh substitusi tepung pisang modifikasi terhadap penurunan kenaikan kadar gula darah pada taraf signifikansi 5\% $(\alpha=0.05)$. data selanjutnya dilakukan uji Duncan sebagai uji lanjut.

\section{HASIL PENELITIAN}

\section{Analisis Fisikokimia Tepung Pisang Termodifikasi}

Pembuatan tepung pisang merupakan salah satu langkah untuk diverifikasi pangan pada buah pisang. Modifikasi tepung pisang dapat merubah karakter kimia dari tepung pisang tersebut sehingga dapat menaikan kadar pati resiten dan menurunkan nilai indeks glikemik pati/daya cerna pati. Pada penelitian ini dilakukan pengukuran kadar air, daya cerna pati secara in vitro, dan kadar pati resisten pada tepung pisang modifikasi. Hasil pengukuran tepung pisang modifikasi dapat dilihat pada tabel 1 .

\section{Tabel 1. Hasil Analisis Fisikokimia Tepung Pisang Modifikasi}

\begin{tabular}{lccc}
\hline Sampel & $\begin{array}{c}\text { KA } \\
(\boldsymbol{\%})\end{array}$ & $\begin{array}{c}\text { RS } \\
(\boldsymbol{\%})\end{array}$ & $\begin{array}{c}\text { DCP } \\
(\boldsymbol{\%})\end{array}$ \\
\hline Tepung & & & \\
Pisang & $4.38 \pm 0.02$ & $20.47 \pm 0.11$ & $22,4 \pm 0.04$ \\
Modifikasi & & & \\
\hline Keterangan & & \\
KA=kadar air & & \\
RS = Kadar Pati Resisten & & \\
DCP = Daya Cerna Pati &
\end{tabular}

Tabel 1. menunjukkan hasil analisis tepung pisang modifikasi berdasarkan kadar air, kadar pati resisten dan daya cerna pati. Berdasarkan tabel tersebut, nilai rata-rata kadar 
air sebesar 4,38\%, kadar pati resisten $20.47 \%$, dan daya cerna pati sebesar $22,40 \%$.

\section{Pengaruh Konsentrasi Tepung Pisang pada Pembuatan Kabosol Terhadap Kadar Gula Darah}

Pada pembuatan kabosol, faktor yang digunakan adalah perbedaan konsentrasi tepung pisang modifikasi. konstentrasi tepung pisang modifikasi yang digunakan adalah $50 \%, 75 \%, 100 \%$, dan 0\% sebagai kontrol. Produk Kabosol tersubstitusi tepung pisang modifikasi selanjutnya dicobakan pada orang dewasa dan diukur kadar gula darah puasa (GDP) dan kadar gula darah sewaktu (GDS). Parameter yang diukur pada penelitian ini adalah kenaikan gula darah orang dewasa normal. Hubungan konsentrasi tepung pisang modifikasi dengan nilai kenaikan gula darah dan penurunan kenaikan gula darah orang dewasa dapat dilihat pada tabel 2 .

Tabel 2. Hubungan Konsentrasi Tepung Pisang Modifikasi dengan Kenaikan Kadar Gula Darah Orang Dewasa

\begin{tabular}{cc}
\hline $\begin{array}{c}\text { Konsentrasi } \\
\text { Tepung Pisang } \\
\text { Modifikasi (\%) }\end{array}$ & $\begin{array}{c}\text { Kenaikan Gula Darah } \\
(\mathbf{m g} / \mathbf{d L})\end{array}$ \\
\hline 0 & $24.9 \pm 2.78^{\mathrm{a}}$ \\
50 & $15.2 \pm 1.61^{\mathrm{a}}$ \\
75 & $11.1 \pm 1.85^{\mathrm{a}}$ \\
100 & $3.4 \pm 1.14^{\mathrm{b}}$ \\
\hline
\end{tabular}

bhuruf yang berbeda menunjukkan perbedaan signifikansi pada taraf 5\%

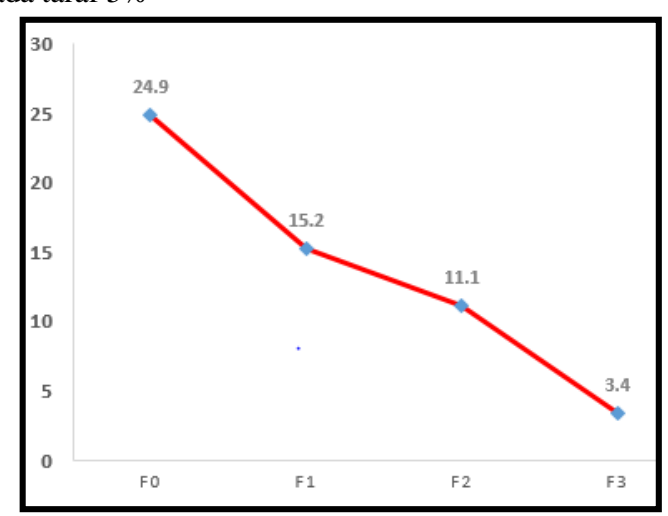

Gambar 1. Grafik hubungan konsentrasi tepung pisang dengan kenaikan gula darah $(\mathbf{F 0}=$ kontrol, $\mathbf{F 1}=$ konsentrasi 50\%, F2= konsentrasi $75 \%$, F3= konsentrasi $100 \%$ )
Kenaikan gula darah ditentukan dengan membandingkan gula darah puasa (GDP) dengan gula darah sewaktu (GDS). Tabel 2 menunjukkan hubungan konsentrasi tepung pisang modifikasi dengan nilai kenaikan gula darah $(\mathrm{mg} / \mathrm{dL})$. Berdasarkan tabel 2, kabosol yang dibuat dengan substitusi tepung pisang modifikasi dengan konsentrasi berbeda memberikan nilai kenaikan gula darah yang berbeda. Data yang dihasilkan dari tabel 2. menjelaskan bahwa semakin tinggi konsentrasi tepung pisang modifikasi maka semakin kecil kenaikan gula darah. Rancangan percobaan yang digunakan pada pembuatan kabosol tersusbtitusi tepung pisang modifikasi terhadap nilai penurunan kenaikan gula darah adalah rancangan acak lengkap (RAL) dan dianalisis dengan uji ragam pada taraf signifikansi $5 \%$.

Berdasarkan uji ragam menunjukkan hasil yang signifikan $(\mathrm{p}<0.05)$ artinya ada pengaruh substitusi tepung pisang modifikasi terhadap kenaikan gula darah. Uji lanjut yang digunakan adalah uji Duncan. Berdasarkan uji Duncan menunjukkan bahwa kabosol yang dibuat dengan konsentrasi pisang 100\% berbeda nyata dengan ketiga bahan lain terhadap kadar kenaikan gula darah pada taraf signifikansi $5 \%$.

\section{PEMBAHASAN}

\section{Analisis Kimia Tepung Pisang Termodifikasi}

Pembuatan tepung pisang merupakan salah satu langkah untuk diverifikasi pangan pada buah pisang. Modifikasi tepung pisang dapat merubah karakter kimia dari tepung pisang tersebut sehingga dapat menaik an kadar pati resiten dan menurunkan nilai indeks glikemik pati/daya cerna pati. Pada penelitian ini dilakukan pengukuran kadar air, daya cerna pati secara in vitro, dan kadar pati resisten pada tepung pisang modifikasi. Hasil pengukuran tepung pisang modifikasi dapat dilihat pada tabel 1 .

Tepung pisang modifikasi yang dibuat pada penelitian ini harus memiliki kadar air yang rendah. Menurut SNI 01-2841-1995, nilai kadar air suatu produk tepung pisang harus di bawah $12 \%$. Kadar air merupakan banyaknya air yang terkandung dalam bahan yang dinyatakan dalam persen. Kadar air suatu produk mengindikasikan mutu dan kualitas produk olahan pangan. Kadar air merupakan 
faktor penting dalam menentukan umur simpan produk pangan. Hal ini berkaitan dengan sifat air yang dapat mempengaruhi sifat fisik, perubahan kimia, perubahan mikrobiologi, dan perubahan enzimatik. Nilai kadar air yang rendah pada produk tepung cenderung memiliki daya simpan yang lebih lama. Pada penelitian ini, nilai kadar air tepung pisang modifikasi diperoleh sebesar $4.38 \%$. berdasarkan penelitian Yuliana dkk (2014) pada pembuatan tepung pisang menghasilkan kadar air sebesar $8.33 \%$.

Pati resisten merupakan fraksi dari pati yang tidak dapat dicerna oleh enzim pencernaan ( $\alpha$ - amilase) dalam usus halus manusia tetapi masih dapat difermentasi oleh mikroflora usus. Semakin tinggi kadar pati resisten pada poduk pangan yang kaya karbohidrat, maka semakin tinggi jumlah pati yang tidak dapat dicerna, artinya semakin sedikit jumlah gula yang ada dalam karbohidrat yang dapat dicerna sehingga tidak mengakibatkan kenaikan gula darah secara signifikan. Pada penelitian ini, kadar pati resiten pada tepung pisang modifikasi diperoleh sebesar 20,47\%. Nilai ini menunjukkan bahwa, dalam 100 gram pati pada tepung pisang modifikasi, Terdapat 20,47 gram pati yang tidak dapat dicerna. Kadar pati resiten ini dapat ditingkatkan dengan pemanasan dan pendinginan berulang. Berdasarkan hasil penelitian Musita (2012), kadar pati resisten pada tepung pisang dihasilkan sebesar 12,24\%. Agustin (2014) melakukan penelitian tentang modifikasi tepung pisang yang menghaslkan kadar pati resisten sebesar $12.73 \%$. Nurhayati dkk (2014) melaporkan hasil penelitiannya yang menunjukkan bahwa kadar pati resisten pada tepung pisang modifikasi dengan proses berulang menghasilkan kadar pati resisten sebesar 42,68\%. Lumba dkk (2017) juga melaporkan hasil penelitian terkait modifikasi tepung pisang dengan proses fermentasi dan pemanasan berulang yang dapat meningkatkan kadar pati resisten dari $10,73 \%$ menjadi $48,53 \%$.

Modifikasi tepung pisang yang dilakukan pada penelitian ini juga dapat mempengaruhi nilai daya cerna pati. Daya cerna pati merupakan tingkat kemudahan suatu jenis pati untuk dapat dihidrolisis oleh enzim pemecah pati menjadi unit-unit yang lebih kecil. Semakin tinggi nilai daya cerna pati, maka semakin mudah pati tersebut dicerna oleh enzim pencernaan menjadi gula sederhana dan meningkatkan resiko peningkatan kadar gula darah. Sedangkan semakin rendah daya cerna pati, maka semakin susah pati tersebut dicerna oleh enzim pencernaan menjadi gula sederhana sehingga dapat mengontrol kadar gula dalam darah dan mengurangi resiko peningkatan kadar gula darah. Modifikasi tepung pisang dengan proses pemanasan dan pendinginan dapat mengurangi nilai daya cerna pati. Hal ini selama proses pemanasan dan pendinginan menjadikan struktur pati semakin kompak dan terbentuk ikatan hidrogen (retrodegradasi pati) sehingga susah dicerna oleh enzim pencernaan sehingga dapat menurunkan nilai daya cerna pati. Menurut Nurhayati dkk. (2010), daya cerna pati secara in vitro pada tepung pisang yang dihasilkan dari perlakuan fermentasi dan kombinasi pemanasan pendinginan dapat menurun hingga $50 \%$.

Pada penelitian ini, nilai daya cerna pati yang dihasilkan sebesar 22.40\%. Berdasarkan penelitian Lumba dkk (2017), tepung pisang yang dimodifikasi menggunaan proses fermentasi dan pemanasan memiliki nilai daya cerna pati berkisar antara 21,94\% sampai 49,04\%. Claudia dkk (2016) juga melaporkan pada penelitian daya cerna pati biskuit berkisar antara $22.21 \%$ hingga $74.41 \% \mathrm{~g}$.

\section{Pengaruh Konsentrasi Tepung Pisang pada Pembuatan Kabosol Terhadap Kadar Gula Darah}

Salah satu faktor yang mempengaruhi kenaikan gula darah orang dewasa normal adalah komposisi bahan pangan yang dikonsumsi. Kandungan bahan pangan yang mempengaruhi kenaikan gula darah adalah kadar serat, perbandingan amilosa dan amilopektin, daya cerna pati, kadar pati resisten, kadar lemak dan protein. Masingmasing komponen tersebut memberikan kontribusi dan saling berpengaruh hingga menghasilkan respons glikemik yang berbeda (Arif \& Budiyanto, 2013). Semakin tinggi nilai indeks glikemik suatu bahan pangan, maka akan semakin cepat menaikan kadar gula darah pada orang yang mengkonsumsi bahan makanan tersebut. Pangan yang memiliki nilai indeks glikemik rendah dapat mengurangi 
kenaikan kadar gula darah sehingga kadar gula darah orang yang mengkonsumsi bahan pangan dengan indeks glikemik rendah dapat dikontrol dengan baik

Kue kabosol yag dibuat pada penelitian ini berbahan baku tepung pisang modifikasi. Tepung pisang modifikasi yang dibuat pada penelitian ini memiliki nilai indeks glikemik rendah. Hal ini dibuktikan dengan pengukuran nilai daya cerna pati yang rendah dan kadar pati resiten yang tinggi.

Kabosol yang dibuat dengan substitusi tepung pisang modifikasi dengan konsentrasi berbeda memberikan nilai kenaikan gula darah yang berbeda. Hasil penelitian menunjukkan bahwa kabosol yang dibuat dengan tepung pisang dengan konsentrasi $100 \%$ memberikan nilai kenaikan gula darah yang terendah yaitu $3.1 \mathrm{mg} / \mathrm{dL}$. Hal ini dikarenakan kabosol tersubstitsu tepung pisang $100 \%$ mengandung pati resisten lebih tinggi dan daya cerna pati lebih rendah dibandingkan dengan perlakuan lain. Responden yang mengkonsumsi kabosol dengan konsentrasi pisang 100\% lebih dapat mengontrol kadar gula darahnya dibandingkan kontrol ataupun perlakuan lainnya.

Berbagai penelitian yang sejalan telah melaporkan terikait hubungan pangan dengan nilai indeks glikemik berbeda, memberikan nilai kenaikan kadar gula daah yang berbeda juga. Berdasarkan penelitian Mayawati (2017), menunjukkan bahwa responden yang mamiliki asupan makanan indeks glikemik tinggi $(65,4 \%)$ dapat meningkatkan kadar glukosa darah yang tinggi $(69,2 \%)$. Berdasarkan Penelitian Susanti (2018), ada hubungan antara pola makan pada pangan yang memiliki indeks glikemik tinggi terhadap kadar gula darah pada penderita Diabetes Mellitus di Puskesmas Tembok Dukuh Surabaya. Astuti (2017) melaporkan bahwa terdapat hubungan signifikan antara kebiasaan konsumsi pangan IG tinggi dengan kadar gula darah pasien DM tipe II $(\mathrm{p}=0,016)$. Berdasarkan penelitian Nursalam dkk (2016) melaporkan bahwa penambahan tepung pisang dan sukun pada mie dapat menurunkan kenaikan nilai gula darah sesaat pada responden orang dewasa normal.

\section{KESIMPULAN}

Substitusi tepung pisang modifikasi pada pembuatan kabosol memberikan pengaruh terhadap penurunan kenaikan kadar gula darah orang dewasa. Kenaikan kadar gula darah semakin turun dengan semakin tinggi konsentrasi tepung pisang modifikasi yang ditambahkan. Kenaikan kadar gula darah terendah diperoleh dari konsentrasi tepung pisang $100 \%$. Kabosol dengan susbstitusi tepung pisang modifikasi $100 \%$ dapat dijadikan sebagai pangan fungsional karena dapat mengontrol kadar glukosa dalam darah.

Saran pada penelitian ini adalah antara lain perlu dilakukan optimasi proses modifikasi tepung pisang untuk lebih meningkatkan kadar pati resisten dan menurunkan daya cerna pati, dilakukan optimasi formulasi produk kabosol untuk mendapatkan formula terbaik terhadap uji organoleptik, dan tepung pisang modifikasi diaplikasikan ke produk olahan lain yang lebih cocok seperti brownis.

\section{DAFTAR PUSTAKA}

Abdillah, F. (2010). Modifikasi Tepung Pisang Tanduk (Musa paradisiaca Formatypica) Melalui Proses Fermentasi Spontan dan Pemanasan Otoklaf untuk Meningkatkan Kadar Pati Resisten (Tesis). Bogor. Program Pascasarjana Institut Pertanian Bogor.

Agustin, S. (2014). Potensi Tepung Pisang Kapas Sebagai Sumber Pati Resisten Melalui Modifikasi Ditingkat Pati. Prosiding seminar nasional kimia

Anderson, A.K., Guraya, H.S., James, C., Salvaggio, L. (2002). Digestibility and pasting properties of rice starch heatmoisture treated at the melting temperature $(\mathrm{Tm})$. J Starch/Starke 54: 401-409.

AOAC. (1995). Official Methods of Analysis of the Association Analytica 1 Chemistry Inc., Washington D. C.

AOAC. (2005). Official Method of Analysis of the Association of Official Analitycal Chemists. $18^{\text {th }}$ ed. Maryland: AOAC International. William Harwitz (ed). United States of America.

Arif, A., Bin, Budiyanto, A. (2013). Glicemic Index of Foods and Its Affecting Factors. Jurnal Litbang Pertanian, 32(2)

Astuti, A., Maulani. (2017). Pangan Indeks Glikemik Tinggi dan Gula Darah Pasien Diabetes Mellitus Tipe II. Jurnal Endurance. 2(2) : 225-231 
Aurore, G., Parfait, B., Fahrasmane, L. (2009). Bananas, raw materials for making processed food products. J Trends in Food Science \& Technology. 20: 78 - 91

Baba, M.D., Manga, T.A., Daniel, C., Danrangi, J. (2015). Sensory Evaluation of Toasted Bread Fortified with Banana Flour: A Preliminary Study. American Journal of Food Science and Nutrition. 2(2): 9-12

Badan Standarisasi Nasional. (1995). SNI 013841-1995. Standar Mutu Tepung Pisang. Jakarta : Badan Standarisasi Nasional.

Claudia, E.J., Widjanarko, S.B. (2016). Studi Daya Cerna (In Vitro) Biskuit Tepung Ubi Jalar Kuning dan Tepung Jagung Germinasi. Jurnal Pangan dan Agroindustri 4(1) : 391-399

Dundar, A.N., Gocmen, D. (2013). Effects of autoclaving temperature and storing time on resistant starch formation and its functional and physicochemical properties. Carbohyd Polym 97: 764-771

Emanuel, C. (2005). Pengaruh Fosforilasi dan Penambahan Asam Stearat Terhadap Karakteristik Film Edible Pati Sagu. [Tesis]. Bogor: Program Pascasarjana, Institut Pertanian Bogor.

KEMENTAN. (2014). Total produksi pisang tahun 2013-2014. Jakarta (ID)

Kusnandar, F., Hastuti, H.P., Syamir, E. (2015). Pati Resisten Sagu Hasil Proses Hidrolisis Asam dan AutoclavingCooling. Jurnal Teknologi dan Industri Pangan. 26(1): 52-62

Kustanti, I.H., Rimbawan, Furqon, L.A. 2017. Formulasi Biskuit Rendah Indeks Glikemik (BATIK) Dengan Subtitusi Tepung Pisang Klutuk (Musa balbisiana Colla) dan Tepung Tempe. Jurnal Aplikasi Teknologi Pangan. 6 (1) : 1218

Langi, T., Koapaha, T. 2(014). Using Goroho Banana Flour as a Substitute in Making Cookies Rolls. International Conference on Food, Agriculture and Biology: 1416

Lumba, R., Djarkasi, G.S., Molenaar, R. (2017). Modifikasi Tepung Pisang "Mulu Bebe" (Musa Acuminata) Indigenous Halmahera Utara Sebagai Sumber Pangan Prebiotik. Jurnal Teknologi Pertanian. 8(1)
Maya, H., Isnaeni, F.N. (2017). Hubungan Asupan Makanan Indeks Glikemik Tinggi dan Aktivitas Fisik dengan Kadar Glukosa Darah pada Pasien Diabetes Melitus Tipe II Rawat Jalan di RSUD Karanganyar. Jurnal Kesehatan. 10(1) : 75-84

Napitupulu, D.S., Karo, T.P., Lubis, Z. (2013). Pembuatan Kue Bolu dari Tepung Pisang Sebagai Substitusi Tepung Terigu dengan Pengayaan Tepung Kedelai. Jurnal Rekayasa Pangan dan Pertanian. 1(4) : 14-19

Nasrin, T.A.A., Anal, A.K. (2014). Resistant starch III from culled banana and its functional properties in fish oil emulsion. Food Hydrocolloid 35: 403409

Nurhayati, Laksmini, B.S., Widowati, Kusumaningrum. (2014). Komposisi Kimia dan Kristalintas Tepung Pisang Termodifikasi Secara Fermentasi Spontan dan Siklus Pemanasan Bertekanan Pendinginan. Jurnal AGRITECH. 34(2)

Norhidayah, M., Noorlaila, A., Izzati, N.F. ( 2016). Textural and sensorial properties of cookies prepared by partial substitution of wheat flour with unripe banana (Musa x paradisiaca var. Tanduk and Musa acuminata var. Emas) flour. International Food Research Journal. 21(6): 2133-2139

Nursalam, Fauziningtyas, R., Asmoro, C.P., Kusnanto, Adriani, M. (2016). Efek Mie Pisang dan Sukun Terhadap Gula Darah Sewaktu. Jurnal Ners. 11(2) : 246-250

PUSDATIN. 2014. Pusat Data dan Informasi Kementrian Kesehatan RI

Ozturk, S., Koksel, H., Kahraman, K, Ng PKW. (2011). Production of resistant starch from acidmodified amylo type starches with enhanced functional properties. Journal Food Eng 103: 15664.

Rimbawan, Siagian, A. (2004). Indeks Glikemik Pangan, Cara Mudah Memilih Pangan yang Menyehatkan. Penebar Swadaya. Jakarta

Silvia. (2012). Pengaruh Substitusi Tepung Pisang pada Pembuatan Brownies terhadap Sifat Kimia dan Penerimaan Organoleptik. Jurnal Litbang Industri. 2(2) : 71-78 
Susanti, Bistara, D.N. (2018). Hubungan Pola Makan dengan Kadar Gula Darah pada Penderita Diabetes Mellitus. Jurnal kesehatan Vokasional. 3(1) : 29-34

Yuliana, Novitasari, R. (2014). Pengaruh Substitusi Tepung Terigu dengan
Tepung Pisang Kepok (Musa Paradisiacal Formatypica) terhadap Karakteristik Mie Kering yang Dihasilkan. Jurnal Teknologi Pertanian. 3(1) : 1-1. 